\title{
Effectiveness of Zakah in Fulfilling Daruriyat/Basic Needs and Elevating The Zakah Recipients Standard of Living to Hajiyat/Comfortable Life in The Perspective of Maqasid al-Syariah
}

(Keberkesanan Zakah dalam Memenuhi Daruriyat/Keperluan Asas dan Mempertingkat Kehidupan Penerima Zakah ke Tahap Hajiyat/Kesenangan dalam Perspektif Maqasid alSyariah)

\author{
Maheran Zakaria \\ Norhayati Samba Mohamad \\ (Faculty of Accountancy, Universiti Teknologi MARA Kelantan)
}

\section{ABSTRACT}

This study explores zakah recipients' perceptions of daruriyat/basic needs and examines the effectiveness of zakah funds to fulfill the needs and elevate recipients' standard of living to hajiyat/comfort living. Data were gathered from in-depth interviews and focus group discussions with Majlis Agama Islam Kelantan (MAIK)'s zakah recipients. The data were audio-recorded, transcribed verbatim and analysed qualitatively by referring to daruriyat/basic needs of Maqasid al-Syariah. Results indicated that recipients perceive daruriyat needs as needs consisting of property, life, lineage and intellect. They also perceived that zakah has successfully assisted them in fulfilling the needs but has yet to elevate their life to the standard of hajiyat/comfort. Although faith is one of the Maqasid al-Syariah daruriyat elements and paramount in one's life, none highlighted it as important. This provides useful insights to zakah agency to educate recipients on the importance of faith and rejuvenate its programs so that the recipient's standard of living would be raised to a higher level. The goal of Maqasid al-Syariah in zakah jurisprudence will be achieved, if zakah funds successfully fulfil all the five elements of daruriyat needs (faith, property, life, lineage and intellect) and elevate recipients'standard of living to the standard of hajiyat/comfort.

Keywords: Basic needs; daruriyat; Maqasid al-Syariah; recipients; zakah

\section{ABSTRAK}

Kajian ini meninjau persepsi penerima zakah terhadap keperluan daruriyat/asas. Kajian ini juga mengkaji kemampuan dana zakah dalam memenuhi keperluan tersebut dalam mengubah kehidupan mereka ke tahap hajiyat/kesenangan. Data dikutip melalui temubual secara mendalam dan perbincangan antara kumpulan fokus dengan penerima zakah Majlis Agama Islam Kelantan (MAIK). Data direkod secara audio, ditranskrip secara verbatim dan dianalisa menggunakan kaedah kualitatif dengan merujuk kepada keperluan daruriyat seperti yang terkandung dalam Maqasid al-Syariah. Penemuan menunjukkan responden beranggapan bahawa keperluan daruriyat/asas terdiri dari harta, nyawa, keturunan dan akal. Mereka juga bertanggapan bahawa zakah telah berjaya memenuhi keperluan tersebut tetapi belum dapat mengubah kehidupan mereka ke taraf hajiyat/kesenangan. Walaupun keperluan kepada agama adalah yang terpenting dalam kehidupan seseorang berdasarkan Maqasid al-Syariah, tiada penerima mengatakan ianya penting. Oleh itu, agensi zakah perlu memahamkan penerima zakah terhadap pentingnya keperluan kepada agama di samping merejuvenasi program agar dapat mengubah kehidupan penerima ke tahap yang lebih tinggi. Matlamat Maqasid alSyariah dalam jurispruduksi zakah akan tercapai sekiranya zakah dapat memenuhi kesemua 
lima keperluan daruriyat (agama, harta, nyawa, keturunan dan intelek) dan berjaya mengubah taraf kehidupan mereka ke tahap hajiyat/kesenangan.

Katakunci: Keperluan asas; daruriyat; Maqasid al-Syariah; penerima; zakah

\section{INTRODUCTION}

Paying zakah or alms giving is the third out of five pillars in Islam. The order of paying zakah comes after performing solah (prayer) and is always recited simultaneously in the Noble Qur'an as both refer to purification. Purification of one's soul and wealth for the will of Allah SWT would bring one closer to the Creator, Allah SWT. The importance of both rituals has been stressed for more than fifty times in the Noble Qur'an. In Al-Qur'an 2:3, Allah SWT commands, that is interpreted as, "Establish solah and give zakah and bow with those who bow in worship and obedience." Since then, paying zakah has become a religious duty for every Muslim whose wealth and earnings exceed one's self sufficiency for one whole lunar year.

The zakah collections are distributed to eight eligible recipient groups known as asnaf. This is prescribed in Al-Quran 9: 60 which is interpreted as "Zakah is meant for the fuqara (destitute), who are insufficient of daruriyat/basic needs, masakeen (the needy), who are able to fulfill daruriyat/ basic needs but their earnings have yet to fulfill other important needs, amilin, who help in distributing the zakah funds, fisabillillah, who fight for the sake of religion, muallaf (new convert Muslim), gharimin, who are heavily indebted and unable to settle their debts, Ibn Sabil (wayfarer), those who run out of food ration in their travel for a good cause, and riqab (for freeing a Muslim from bondage whether a slave in the old times, or in this day Muslims who have problem in their faith towards Islam, and those involved in prostitution or drug addiction.

Zakah is an honourable deed, apart from creating a closer relationship between the payer and Allah SWT, it establishes a strong connection between the payers and recipients. Consequently, it reduces the feelings of hatred, jealousy and uneasiness among the recipients towards the payers. In an equal manner, the payers are purified from vice deeds such as selfishness, greediness and avarice. Eventually, this nurtures a sense of belonging, brotherhood, solidarity, sensibility, generosity and empathy which leads to a fair, responsible and united society.

The beauty of zakah system prevailed during the reign of Caliph Umar al-Khattab, in which the system had successfully transformed recipients' destitute state into an affluent life This led to surplus in the zakah funds as there were no eligible recipients to receive them (al Qardhawi 1987; al Zuhaili 2005). The surplus funds were subsequently channelled to other productive activities to stimulate robust economy and develop community welfare.

The main objective of zakah is to incorporate a system for equitable distribution of income and wealth among the society members so that every member will get his contribution and no members should deprive others of their share. The equality concept does not mean that everyone is regarded equally but it emphasizes on economic justice. One should meet and fulfil his/her self-sufficiency of at least the acceptable requirement of daruriyat/basic needs. Daruriyat/basic needs are not confined to monetary items only (Rosbi \& Sanep 2009), as one strives to fulfil other non-monetary needs that include food, shelter, social, knowledge, family and religion. Deprivation of any of the elements would affect one's self-sufficiency and lead $\mathrm{him} /$ her to remain in the brink of poverty. The second objective of zakah is to purify Muslims' soul and heart from the love of wealth and possession, parsimony and greed through the transfer of excessive wealth to the needy.

In the Malaysian system, the collection and distribution of zakah funds are placed under the auspices of every state religious council. Malaysia consists of 13 states and 1 Federal 
Territory (constitutes of Wilayah Persekutuan and Labuan). Every state and Federal Territory has its own Islamic Religious Council (SIRC). For Kelantan, the management of zakah funds is under the purview of Kelantan Islamic Religious Council which is commonly known as Majlis Agama Islam Kelantan (MAIK).

The statistics for the year 2016 indicated that people in the state of Kelantan had the lowest monthly median income of RM3,077 per household, by comparing to other states. To date, Malaysians have been levelled into three different income groups namely Top 20\% (T20), Middle 40\% (M40), and Bottom 40\% (B40). T20 consists of 20\% of Malaysians whose monthly mean income is above RM13,148 per household. M40 represents $40 \%$ of Malaysians who earn between the range from top to bottom income. Meanwhile, B40 represents those whose mean income is at the bottom line, of RM3,000 per household, which accounted for $40 \%$ of Malaysians. The average monthly median income for Malaysians was RM5,228 per household and those living in Federal Territory enjoying the highest median income of RM9,073 per household (Malaysian Statistic Department,2016).

The phenomenon indicates that the Kelantaneses' mean incomes are slightly above the B40 group. $89.5 \%$ of them are Malays (Malaysian Statistic Department 2016) and based on Article 160 of the Federal Constitutions, a Malay is a person who professes the religion of Islam. Although, statistics indicated that zakat distributed by MAIK has been gradually increased (zakah distributions for 2015 and 2016 were RM161.3 and RM164.6 million respectively, MAIK 2017), the incidence of poverty in the state persists at $0.08 \%$. Even worse, people in the state of Kelantan earned the lowest median household income as opposed to other Malaysians.

This contradicts with the phenomenon during the reign of Caliph Umar Ab.Aziz, whereby in his era, zakah had successfully fulfilled recipients' daruriyat/basic needs and even transformed them from being penurious to being wealthy that is either at the level of hajiyat/comfort or even tahsaniyat/luxury. Ironically, in the later situation, zakah has yet to fulfil its objective; the underprivileged groups who barely fulfil their daruriyat/basic needs still exist and thus remain in the poverty list.

\section{LITERATURE REVIEW}

Islam outlines three levels of standard of living in one's life namely daruriyat/basic, hajiyat/comfort and tahsaniyat/luxury as prescribed in Maqasid al-Syariah. The Maqasid alSyariah indicates that the standard of living starts from daruriyat followed by hajiyat and finally the highest level, tahsiniyat. These three levels of standard of living standard are interrelated whereby after achieving the lowest level, one strives for the next higher level. Daruriyat refers to the basic needs that one resorts to fulfil for him and his dependency. The dependents include spouse, children who are unable to earn their living, and parents who are in need. Daruriyat needs consist of five elements namely preservation of faith, life, intellect, lineage and property (Auda 2008).

Preservation of faith is the utmost essential needs in one's life. All matters of Muslim's life and death should align to Allah S.W.T command in order to be blessed by Him in this world and the hereafter. Preservation of life relates to basic needs needed by one to continue his/her daily lives such as food, clothes and medicines. Preservation of intellect is important so that one can interact and socialise in the society. Preservation of lineage relates to honour, dignity and pride that one needs to protect himself and his family. Preservation of property refers to wealth or income that one needs to possess for a decent, comfortable and humane living. According to Maqasid al-Syariah, these five elements are essential elements in one's life (Auda 2008). Hence, failure to fulfil any of the elements of daruriyat needs would impair one's standard of living and as a result his/her life has no quality (Mahyudin \& Abdullah 2011). 
The standard of hajiyat/comfort emerges after one fulfils daruriyat needs. Hajiyat is less essential for human life such as marriage, trade, transportation and eating preferable type of food. Islam encourages this need, but it is not a matter of life and death. Tahsaniyat or luxury is living elements that become a symbol of one's wealth (Mahyudin \& Abdullah 2011). It is the paramount level of needs in which one achieves the highest level of standard of living. Tahsaniyat is encouraged by Islam; however, it takes a lower priority and less emphasized in one's life.

The common measurement of basic needs for many countries in the world is based on unidimensional element that is gross monthly income. In Malaysia, one is classified poor if his gross monthly income is below than Poverty Line Income (PLI). The PLI is set by Economic Planning Unit at RM800 monthly income. This income is deemed sufficient for a household that consists of 4 to 6 people to meet the basic needs that include food and non-food items for a month (Economic Planning Unit, JPM 2009, 10 ${ }^{\text {th }}$ Malaysia Plan 2011-2015).

Indeed, basic needs consist of multi-dimensional elements and therefore should be assessed in a wider context (Rosbi \& Sanep 2009). They suggested that basic needs should be evaluated according to the needs in the perspective of Maqasid al-Syariah that stress on faith, property, life, lineage and intellect. One needs to fulfil daruriyat needs for a decent, humane and respectable standard of living. Hence, the needs prescribed by the Maqasid al-Syariah is expected to provide an accurate, fair and comprehensive assessment or even a more holistic view of one's self-sufficiency.

To date, many empirical studies have examined the efficiency of zakah agency and Islamic Microcredit based on the fulfilment of recipient's daruriyat/ basic needs by using quantitative approach (Alam, Said \& Hassan 2015; Rosbi \& Sanep 2009; Zakaria \& Abd Malek 2014; Zakaria 2014). Alam et al. (2015) examined the efficiency of microcredit in fulfilling the borrower's daruriyat needs as stipulated by Maqasid al-Syariah. The study was conducted on 393 microcredit borrowers of Amanah Ikhtiar Malaysia (AIM) in the state of Sabah and Peninsular Malaysia. Results indicated that the higher fulfilment of borrower's daruriyat needs, the higher is the efficiency of microcredit agency.

Zakaria and Abd Malek (2014) investigated the effect of fulfilling daruriyat needs in the perspective of Maqasid al-Syariah on the efficiency of zakah distribution among 320 zakat recipients of business assistant program conducted by Kelantan Islamic Religious Council. The efficiency of zakah was measured using Balanced Score Card. Employing SEM and using AMOS analysis, the results indicated that the fulfillment of recipient's daruriyat needs was positively related to the efficiency of zakah agency. Zakaria (2014) replicated the study of Zakaria and Abd Malek (2014) and gauged on 275 zakat recipients of Business Program of Lembaga Zakat Selangor. Adopting SEM and using PLS analysis, the results concurred with prior study in which the higher the fulfilment of recipient's daruriyat needs, the higher was the efficiency of zakat agency in distributing zakat.

Rosbi and Sanep (2009) examined the efficiency of Lembaga Zakat Selangor by a Business Program in relation to the fulfilment of daruriyat needs of Maqasid al-Syariah. This study conducted an analysis of Change Assessment and Scoring tool (CAST) analysis and found that zakat agency was perceived efficient if it was able to fulfill the recipient's daruriyat needs specifically for the elements of religion and physical self.

However, all of the above mentioned studies were quantitative in nature. One of the drawbacks of the quantitative research is the outcome might be too general for direct application to specific contexts. To overcome this methodological issue, a qualitative research is required in which the respondents will lend themselves to exploring how and why the phenomenon of poverty or shoody standard of living persists.

To the best knowledge of the authors, there is a dearth of study that analysed the zakah recipients' perceptions on the elements of daruriyat/basic needs as prescribed by Maqasid al- 
Syariah and the ability of zakah in fulfilling those needs and transforming them to a higher level using a qualitative approach. To bridge this void, at least partially, the first objective of this study is to explore on how zakah recipients' perceive the elements of daruriyat needs. The second objective is to explore on how zakah recipients' perceive zakah funds will provide them a better life.

\section{METHODOLOGY}

This study was carried out in the state of Kelantan which is situated in the east coast of Peninsular Malaysia. The management of zakah affairs for this state is under the purview of Kelantan State Religious Islamic Council or MAIK (Majlis Agama Islam Kelantan). As of 2016, MAIK has initiated 18 zakah distribution programs (Hamat 2012). Respondents for this study were chosen from two programs namely business assistance and sewing course. These two programs were designed to promote recipient's economic activities and thus, they are expected to propel in transforming their standard of living in the long run. Meanwhile, other remaining zakah programs are given to elderly, those with prolonged sickness, the disabled and children who have lack of capability to generate income. The funds are meant to assist them in fulfiling their daruriyat/basic or minimum standard of living on a short-term basis. Once given, the funds are dispensed to the recipients to make their ends meet.

\section{RESEARCH METHOD}

This study required respondents to answer open-ended questions and encouraged them to respond without imposing any restriction. This principle does not anticipate any pattern of response whereby the respondents are free to express their views. They were given careful and detailed clarification; any ambiguity would be probed further and facilitated, leading to an indepth analysis. The respondents were selected from the lists of business assistance and sewing program conducted by MAIK in the year 2016 until mid-2017. Unlike hypothesis-driven or quantitative research, this study is qualitative in nature that focuses on in-depth experience of the respondents. It provides analysis of the context involved in the phenomenon under study.

\section{DATA COLLECTION}

Data were collected through two methods; in-depth interview with business assistance program respondents and focus group discussions (FGDs) with sewing program respondents. Different methods were chosen due to the fact that the respondents of business assistant program possess a vast array of demographic profiles, therefore their attitudes, reactions and views are distinctive and unique. With regard to this, individual interviews were deemed to be preferable in the former program in which every single response would be analysed extensively. The FGD respondents were more forthcoming in the latter programme as the respondents were homogenous in nature. Moreover, the sewing programs were conducted in groups, therefore respondents assimilate well with each other. This would encourage and stimulate respondents to voice out their perceptions, feelings and express hidden opinions without shame or guilt (Abdul Ghani et al. 2014). Thus, gathering them in a group would promote an entire view of the group's opinion.

\section{CONDUCT OF IN-DEPTH INTERVIEWS AND FOCUS GROUP DISCUSSION}

The first objective was to explore the respondents' perceptions of the elements of daruriyat/basic needs. The second objective was to examine their perceptions of the effectiveness of zakah funds in fulfilling the needs and raising their living standards to a higher 
level. For both methods, the researcher started the session by introducing herself and thanking respondents for their willingness to participate. Later, the researcher briefly explained to the respondents the study objectives. This session was assisted by another fellow researcher. The session was initiated with a question: "In your opinion, what are the elements of daruriyat (basic needs)?"'The respondents were encouraged to voice out their perceptions of the elements of daruriyat needs. Later, the respondents were asked," Do zakah funds assist you in fulfilling those needs and raising your life to a higher standard?" The respondents were asked to give examples if clarification was needed and expanded it if they like to explain their responses in detail.

The in-depth interviews were carried out with 12 voluntary respondents from business assistance program. Apart from that, 4 focus group discussions (FGD) were conducted; FGD 1 with 5 sewing program students of Jan 2017 intake, FGD 2 with 5 former students of Jan 2016 intake, FGD 3 with 5 former students of Jun 2016 intake and FGD 4 with 5 students of July 2017 intake, totalling 20 respondents. The in-depth interviews and FGDs were audiorecorded with prior consent from the respondents. The in-depth interviews were conducted earlier and took about 30 minutes per session, while the FGDs lasted for 45 minutes per session. All sessions were carried out in the Malay language.

\section{PROFILE OF RESPONDENTS}

The respondents consist of 12 zakah recipients of business assistance (BA) program and 20 zakah recipients of sewing course (SC) program. Every zakah recipient of business assistance program was given a one-off fund, ranging from RM 2,000 to RM 5,000. They were between the age of 35 to 50 years and all of them were married. In terms of gender, six were female and six were male, totalling 12 people.Four FGDs were conducted for former sewing course program's respondents.

Five respondents participated in each FGD, amounting to 20 people. Every respondent received a monthly allowance of RM 300 for eight consecutive months throughout the course. All respondents were female, single and aged between 18 to 25 years. In total, 32 people participated, 12 from the business assistance program and 20 from the sewing course. The profile of respondents is depicted in Table 1.

TABLE 1. The profile of respondents

\begin{tabular}{|c|c|c|c|c|c|c|}
\hline Program & Method & Amount of Zakah Funds & $\begin{array}{l}\text { Age } \\
\text { (year) }\end{array}$ & $\begin{array}{l}\text { Marital } \\
\text { Status }\end{array}$ & Gender & $\begin{array}{l}\text { Number of } \\
\text { Respondents }\end{array}$ \\
\hline $\begin{array}{l}\text { Business } \\
\text { Assistance } \\
\text { (BA) }\end{array}$ & $\begin{array}{l}\text { In-depth } \\
\text { Interview }\end{array}$ & $\begin{array}{l}\text { RM2000 - RM5000 } \\
\text { (one-off payment) }\end{array}$ & $35-50$ & Married & $\begin{array}{l}\text { Female: } 6 \\
\text { Male: } 6\end{array}$ & $\begin{array}{c}12 \\
(\mathrm{R} 1-\mathrm{R} 12)\end{array}$ \\
\hline $\begin{array}{l}\text { Sewing } \\
\text { Course } \\
\text { (SC) }\end{array}$ & $\begin{array}{l}\text { Focus } \\
\text { Group } \\
\text { Discussion }\end{array}$ & $\begin{array}{l}\text { RM300/ month (for } 8 \\
\text { months) }\end{array}$ & $18-25$ & Single & Females: 20 & $\begin{array}{c}20 \\
(\mathrm{R} 1-\mathrm{R} 20)\end{array}$ \\
\hline Total & & & & & & 32 \\
\hline
\end{tabular}

\section{DATA COLLECTION AND ANALYSIS}

The main researcher transcribed verbatim the audio-tapes prior to analysing the data. This was done soon after completion of each session, usually in the same day. She also deleted and lifted all personal and identical information to maintain confidentiality and anonymity. Later, the researcher immersed in the research context by familiarizing herself with the data to experience contextual sensitivity. She would recall how the respondents answered the questions. By doing this, the researcher was able to capture the respondents' facial and verbal expressions together 
with their body movements. This is important to obtain the essence of the interviews and discussions. Furthermore, this accelerates deeper understanding of the actions and words that were expressed in word or implied through actions.

The respondents were encouraged to speak up freely; interpretation of response patterns was formed during the data analysis. The data were then coded (indexes, charted and mapped) for themes. Emerging themes from the interview data and FGD were used for analysis of respondents' perceptions of daruriyat/ basic needs and whether zakah has been successful in fulfilling those needs and transforming them to a better level (hajiyat/comfort or tahsaniyat/luxury).

The audio tapes and transcriptions were further analyzed independently by the second researcher and discussed until a consensus was derived. Excerpts from the interviews were transcribed in Malay language and showed to two individual respondents of business assistance program and to two members of FGD 1 and 2 for validation. They were asked to suggest changes if there are differences to the interpretation of data. Once the suggestions and indicated summaries had been confirmed to accurately reflect the interviews and FGDs points, the excerpts were translated to English language. Important texts were underlined, coded, charted and mapped. This enabled the researchers to identify any similarities and differences that emerged in the raw data. The researchers then identified a thematic framework and interpreted the data by referring to daruriyat/ basic needs prescribed by Maqasid al-Syariah. Key statements were highlighted and categorized into general and sub-themes. However, only the former was referred and aligned to Maqasid al-Syariah.

Additional information was collected from secondary data such as amount of zakah disbursement and other materials furnished by MAIK.

\section{RESULTS \\ DATA ANALYSIS \\ RESPONDENTS' PERCEPTIONS OF DARURIYAT/BASIC NEEDS}

Daruriyat/basic needs are essential to sustain one's self-sufficiency in accordance with Islam or Maqasid al-Syariah. The first objective of this study is to explore the respondents' perceptions of daruriyat/basic needs. Based on the qualitative data analysis, the transcriptions were classified according to several themes and subthemes. Themes that emerged from the data were compared with daruriyat needs prescribed by Maqasid al-Syariah. Four main themes were identified (1) preservation of property (2) preservation of life (3) preservation of lineage and (4) preservation of intellect. These themes were further sub-divided into 16 sub-themes according to the results of the interviews and discussions based on zakah recipients' verbatim responses.

Theme 1: Preservation of Property Results indicated that respondents perceived property as one of the daruriyat/basic needs required for self-sufficiency of a decent life. Based on the excerpts from the in-depth interviews and focus group discussions, the following themes emerged and were classified under preservation of property.

a). Basic needs - money, food and clothes

"Basic needs are what we require in daily life. These include money, food, clothes, amenities and other utilities".

(BA-R1)

"I do not want more, I just need sufficient food".

(BA-R3)

"I need money to operate a business".

(BA-R6)

"I need money to purchase a sewing machine".

(SC-R12) 
b). Quality of dwelling - property

"I need a decent house, everything is sufficient. What I need is living a normal life."

(BA -R7).

"I need a home with basic amenities, which people regard as sufficient for a decent living".

$(\mathrm{BA}-\mathrm{R} 8)$

"I need a decent place for dwelling"

$(\mathrm{BA}-\mathrm{R} 5)$.

"Even though I rent a house, it should be a decent house for our family, not a house with multiple holes"

(BA - R8).

c). Possession - fixed assets and durable goods

"I need a specific machine so that my business would grow".

$(\mathrm{BA}-\mathrm{R} 1)$.

"Sufficient means adequate basic needs, for example, others have cars, I also have a car, there is no need to have more".

(BA-R3).

d). Income and revenue.

"A monthly decent income is important to cover basic expenses".

(BA- R10)

"I need sufficient revenue to make my business progress".

(BA - R3).

Theme 2: Preservation of Life Results indicated that ones are motivated to fulfil their daily needs so that a good well-being would be maintained which is aligned to preservation of life as prescribed by Maqasid al-Syariah. Based on the excerpts, the following themes and sub-themes namely healthcare and nutritious food emerged.

a). Healthcare and nutrition

"We need to have good health. Being healthy is an essential condition that pushes me to work harder and earn income to fulfill my family's needs. Recently, my health is deteriorating due to lung infection. This prevents me from working hard and also limits my income".

(BA - R12).

"We need nutritious food like eggs, salted fish which are enough for a decent life".

(BA - R8).

b). Financial security

"We need adequate working capital to run the business. Zakah funds facilitate in accelerating my cash flow. It helps to sustain my business".

(BA - R11)

Theme 3: Preservation of Lineage The results showed that ones strive to protect their lineage and establish good relationships with the family members and the societal needs which are akin to preservation of lineage as emphasized in Maqasid al-Syariah. The following subthemes were derived from the excerpts of in-depth interviews and focus group discussions.

a) Friendship

"I am happy as through the course, I met many friends and gained more knowledge".

$(\mathrm{SC}-\mathrm{R} 1)$. 
b) Relationship

"We need to be in relationships so that we can rely on each other".

c) Involvement in children's education

"Children need education. I teach my children at night. I don't want them to carry my tradition, living in poverty. I want them to be better than I".

(BA - R3)

d) Parenting Skill

"Basic needs are parenting skills, children's education".

(BA - R7)

"I need assistants, so I ask my children to assist so that they would understand our needs. We can share and endure the moment of bitterness and sweetness in life together".

$$
\text { (BA - R6). }
$$

Theme 4: Preservation of intellect Ones need knowledge to be respected and to boost their self-confidence which is construed as preservation of mind that is prescribed in Maqasid al-Syariaht. The following sub-themes emerged from the excerpts of in-depth interviews and focus group discussions.

a) Education and skills

"Before joining the program, I knew nothing about sewing. Although my mother is a seamstress, I had no interest in it. My interest sparks after joining the sewing course program. Now, I work at home, sewing clothes. I wish to attend embroidery courses so that I can expand my knowledge".

$(\mathrm{SC}-\mathrm{R} 14)$.

"Through the program, we were given motivation and listen to talk on the importance of fulfilling our needs. This boosts our morale on how to succeed in life". $\quad$ (SC-R16).

"Education is important. I need to pursue my studies to level 3. Now I am at level 1. At level 3, I will be taught the techniques of sewing bride's clothes. My dream is to open a boutique one day".

$(\mathrm{SC}-12)$.

b) Self-confidence

"To succeed we need to be confident. After completing the course, with the knowledge obtained, I gained confidence in sewing clothes. Before entering the course, I had no confidence at all".

(SC - R19).

"I need knowledge to develop my self-confidence, like being able to sew children's clothes". $(\mathrm{SC}-\mathrm{R} 5)$.

The themes and sub-themes are indicated in Table 2.

TABLE 2. Themes and sub-themes from in-depth interviews and focus group discussion

\begin{tabular}{ll}
\hline \multicolumn{1}{c}{ Themes } & Subthemes \\
\hline 1. Preservation of property & a. Money, food and clothes \\
& b. Quality of dwelling \\
& c. Possession of fixed assets and durable goods \\
& d. Income and revenue \\
2. Preservation of life & a. Healthcare and nutrition \\
& b. Financial security
\end{tabular}




\begin{tabular}{ll}
\hline 3. Preservation of lineage & a. Friendship \\
& b. Relationship \\
& c. Family \\
& d. Involvement in children's education \\
4. Preservation of intellect & e. Parenting skills \\
& a. Education and skills \\
& b. Self-confidence
\end{tabular}

The second objective is to examine the recipients' perceptions of the effectiveness of zakah funds in fulfilling daruriyat/basic needs. They were also enquired about the ability of zakah funds in transforming their standard of living. Based on the excerpts of in-depth interviews and FGDs, several themes emerged as indicated below:

a). Low Zakah Fund

"The funds assist me to settle my necessities but have yet to elevate my economic status. I am still in the same standard of living"

(BA-R7).

"Unfortunately, the funds given are too low, it is insufficient to purchase the machine that costs about RM 20000. I really need the machine so that I can serve more customers. This small fund can only help to assist operation cost but not to expand my business ".

$(\mathrm{BA}-\mathrm{R} 1)$.

"I requested for RM 10000 to purchase a machine but sadly was given RM 2000 instead. Without the machine, I cannot produce more".

(BA-R4).

"I cannot afford to purchase a sewing machine. I was given a monthly allowance of RM 300 . The money was used to cover part of the expenses incurred during the program. The cost of a complete set of sewing machines is more than RM 2000. Perhaps, I have to apply for another zakah assistance fund".

(SC-R5).

b). Meagree Income

"My income and business do not improve much as I operate within the same operating scale".

(BA - R4).

"Before joining the sewing course, I had no income, but now I get RM500 per month. At least it was better than before".

$(\mathrm{SC}-\mathrm{R} 3)$.

"Zakah funds facilitate my business cash flow but do not make me rich. (BA-R13).

"I make frozen food without using specific tools. Although I receive a lot of orders, I cannot accept them. Making frozen food manually limits the number of production. Sadly, I cannot meet the demand. This prohibits the business to grow". (BA-R8)

"My employer pays me RM 200 basic plus some commission per cloth that I sew. The highest income, I can get is RM 1000 per month. I have to work with others because I cannot afford to purchase a sewing machine".

$(\mathrm{SC}-\mathrm{R} 5)$.

c). Low standard of living

"I do not want to stay in the existing state standard of living, being in the brink of poverty. I wish to achieve a better life because I want to help my family".

(SC-R11). 
" The zakah funds help me to cope with daily needs but it does not help much to uplift my life".

$(\mathrm{BA}-\mathrm{R} 3)$.

"I eat food like eggs, salted fish, salted sauce $(b u d u)$, which are enough for a decent living". $(\mathrm{BA}-\mathrm{R} 8)$.

\section{DISCUSSION}

As an entrusted body for governing and managing zakah funds, it is imperative for zakah agency to explore the daruriyat needs from the recipients' perspective. This enables the agency to focus its effort on assisting recipients in fulfilling those needs so that the recipients' social economy will be optimally maintained.

\section{THE RECIPIENT'S DARURIYAT/BASIC NEEDS}

The recipients' expressions, views and clarifications on basic needs were matched to the daruriyat/ basic needs as stipulated in Maqasid al-Syariah. Aligned to Maqasid al-Syariah, four emerging themes were identified namely preservation of property, preservation of life, preservation of lineage and preservation of intellect. Property is perceived as one of the important daruriyat/basic needs for self-sufficiency, which encompasses money, food, clothes, a decent shelter and basic fixed assets. Empirical studies have shown that the efficiency of zakah agency in distributing zakah funds is positively related to its ability in the fulfilment of preservation of property (Alam et al. 2015; Zakaria 2014; Zakaria \& Abdul Malik 2014).

The second theme identified is preservation of life. The recipients perceived that maintaining good health, having sufficient food and clothes and having financial securities are entailed in the preservation of life. This is another element of daruriyat/ basic needs for a quality well-being that triggers and propels one to work and earn income (Abdul Rasool, Mohd Salleh \& Mohd Harun 2010). Empirically, the preservation of physical life is found to influence the effectiveness of zakah agency in distributing zakah funds (Alam et al. 2015; Rosbi \& Sanep 2009; Zakaria 2014; Zakaria \& Abd Malek 2014).

The third theme is preservation of lineage. Lineage is perceived as one of the daruriyat/basic needs required to be loved and protected for sustainable legacy. This includes the duty to bring up children, parenting skills, protect family's pride, and involve in children's education. Prior studies have also indicated that preservation of lineage is found to be the determining factor of zakah distribution efficiency (Alam et al. 2015; Zakaria 2014; Rosbi \& Sanep 2009).

Finally, the fourth theme is preservation of intellect. Recipients perceived that intellect is another daruriyat/basic needs. Intellect, wisdom and consciousness help to boost one's selfesteem, self-confident and to socialise in a society (Rosbi \& Sanep 2011). The efficiency of zakah distribution by zakah agency is determined by its ability in the preservation of recipients' intellect (Rosbi \& Sanep 2009; Zakaria \& Abd.Malek 2014). Hence, intellectuality is required for one to strategize his/her life to be meaningful and prosperous.

Despite preservation of faith being the utmost important need emphasised in Maqasid alSyariah, it has yet to be viewed as one of the daruriyat elements by any of the recipients. Perhaps, the recipients may view that faith is ingrained in them since birth and therefore they did not resort to this need. Another reason is recipient may have neglected this need because they were instigated by material elements and thus neglected spiritual or non-material element namely faith as one of the daruriyat/basic needs. Indeed, faith is a foundation for all other daruriyat needs commanded by Allah S.W.T. to be fulfilled by Muslims to receive His blessings in this world and the hereafter. 


\section{THE EFFECTIVENESS OF ZAKAH FUNDS IN FULFILLING DARURIYAT/BASIC NEEDS AND ELEVATING THEIR LIVING STANDARDS TO THE STANDARD OF HAJIYAT/COMFORT}

Based on the in-depth interviews and discussions, the results indicated that the recipients perceived the zakah funds as more likely to fulfill their daruriyat/ basic needs but were less likely to improve their standard of living to hajiyat/comfort. One of the reasons were due to low amount of distributed funds. In practice, MAIK disburses a one-off fund in the range of RM 2,000 to RM 5,000 to each zakah recipient who participates in the business assistance program. MAIK also provides for the sewing course program's respondent a monthly allowance of RM300 per person throughout the 8-month program. In both cases, the given amount is sufficient to assist recipients in financing their cash flow or operating expenses but is inadequate to cover the cost of purchasing long-term assets such as machines or tools. The machines are necessary to speed up operation which could increase the number of output, sales and eventually generate more revenue. Without machines, the recipients are barely able to produce to economies of scale, maintain a competitive edge against competitors and thus, unable to improve their standard of living to hajiyat/comfort and even reach tahsaniyat/luxury life.

Machines and tools are essential elements to accelerate the production volume but they are expensive and out of recipients' reach. According to Wahbah al Zuhaily (2005), the zakah assistance should not be confined to monetary aid only, but it can be in other forms such as tools and machines. Such practice has been implemented by Lembaga Zakah Selangor (LZS). LZS is another zakah agency run by the state of Selangor (Selangor is one of the states in Malaysia, situated in the west coast region). Evidences have shown that this practice has been proven to support recipients in transforming their standard of living from the level of daruriyat/basic to hajiyat/comfort life, of which they eventually will no longer become the recipients of zakah (Rosbi \& Sanep 2010).

The results indicated that zakah funds were less likely to increase the income or revenue of business assistance's respondents. They still earn a meagre income or in other words still at the same level of standard of living. For the sewing course respondents, despite majority of them are employed, their average of income is in the range of RM500 to RM1,000 per month. This is below or slightly higher than Malaysian's poverty line index (PLI) which is RM800 monthly per household. According to Malaysian Economic Planning Unit (2015), those who earn less than PLI are classified poor or unable to meet their self-sufficiency or basic needs. Therefore, it is suggested that further assistance in the form of machines and tools should be given to both groups. Machines would help the former group to upscale their production and revenue. Machines also would help the latter group to work of their own accord without relying on others for employment.

The zakah assistance could be given in a large amount, if it would enable recipients to elevate their standard of living to a higher level. This has also been practised by LZS, through which it allocates an initial capital of RM5,000 to a recipient. Once the business has prospered, an additional fund of RM5,000 would be disbursed. On average, the fund can be allocated up to RM100,000, depending on the nature of the business. The business is closely monitored by LZS officers until the recipients succeed. Eventually, evidences show that some of the recipients have reached the level of hajiyat/ comfort and escaped the asnaf circle and managed to run the business without LZS assistance (Rosbi \& Sanep 2011).

The results indicated that the recipients perceived that they remain in the existing daruriyat standard of living but endeavour to live a better life. They expressed satisfaction with their basic meal that consisted of eggs and salted fish. None of them indicated preference for other 
nutritious foods such as butter and milk that promote good living and comfort (Mahyudin \& Abdullah 2011).

\section{MANAGEMENT IMPLICATION}

The results provide implications to zakah agency of the importance of educating zakah recipients about the preservation of faith in every spectrum of one's life. Embracing faith by performing spiritual and religious obligations would purify one's soul and heart and his life would be showered with blessings of the Almighty, Allah S.W.T in this world and the hereafter. The zakah agency should conduct spiritual and religious programs or talks for the recipients before or throughout the disbursement of zakah funds. This would inculcate awareness in the recepients that preservation of faith is the utmost essential element of daruriyat/basic needs prescribed by Maqasid al Syariah (Auda 2009). Hence, the recipients would realise that zakah assistance is given because Islam is concerned about economic inequalities for the welfare of its ummah/followers.

The results also provide implications for zakah agency to rejuvenate its business assistance and sewing programs so that the recipients would be able to elevate their standard of living to a higher level. The funds should not be confined to monetary assistance as it can be distributed in the forms of tools and machines as well. Additionaly, there should not be any threshold to the amount of funds given, depending on its ability to transform the recipients' standard of living.

\section{ACADEMICS IMPLICATION}

The results provide implications to the body of knowledge of zakah literature on the importance of fulfilling recipients' daruriyat needs as prescribed by Maqasid al-Syariah for self-sufficiency. It is hoped that the evaluation of daruriyat needs based on Maqasid al-Syariah would lead to a more holistic, fair and realistic measurement that includes all explicit and implicit needs. Explicit needs are in the form of preservation for property, lineage and physical life, while implicit needs are in the form of preservation for faith and intellect. The results also provide an implication on the importance of transforming living standards from daruriyat/basic into hajiyat/comfort to eradicate poverty.

\section{CONCLUSION}

In a nutshell, the results indicated that the recipients perceived daruriyat/basic needs consisted of preservation of property, lineage, life and intellect. Although faith is the utmost essential element of daruriyat/basic needs as prescribed by Maqasid al-Syariah, no recipient had highlighted this element so far. The results provide useful insghts to zakah agency that the existing practice of solely providing recipients with monetary assistance is insufficient as the agency should impart spiritual and religious knowledge to the recepients. Faith is the paramount need in Islam and its deprivation will classify one as poor and thus remain in the level of daruriyat. Recipients also perceived that zakah funds assisted them in fulfiling their daruriyat/basic needs but had yet to transform their standard of living into the level of hajiyat/comfort. This discovery provides beneficial insights for zakah agency to rejuvenate its existing programs by not restricting the assistance in monetary form only, but also extending to other forms such as tools, equipment and machines. Apart from that, the amount of distributed zakah funds should be uplifted to the level that they are able to elevate the recipients' standard of living. It is hoped that the suggested initiatives will transform the recipients' standard of living from daruriyat/basic needs to hajiyat/comfort or even 
tahsaniyat/luxury and hence they no longer remain in the shackle of poverty. Eventually, this will expedite the country's aspiration to achieve a high income nation status with zero poverty in due time.

\section{ACKNOWLEDGEMENT}

The authors would like to thank the Management of Universiti Teknologi MARA for funding the research grant.

\section{REFERENCES}

Abdul Rasool, M.S, Mohd Salleh, A. \& Mohd Harun, M.F. 2010. Poverty measurement in Malaysia zakat institutions: Non-monetary indicators. Zakat Transformation: From Subsistence to Productive. Proceedings of the $4^{\text {th }}$ ISDEV International Islamic Development Management Conference (IDMAC 2010). 21-22 December, Universiti Sains Malaysia.

Al-Qardawi.1987. Fiqh Al Zakat. Beirut: Muassasah Risalah.

Al -Quran, Al-Taubah verse 60.

Al-Quran, Al-Imran verse 3.

Alam, M.M, Said, J. \& Hassan, S. 2015. Microcredit performance of Islamic in perspective of Maqasid al-Syariah: Case Study on amanah Ikhtiar Malaysia. Humanomics 31(4): 374 384.

Al Zuhaili.W. 2005. Usul al Fiqh al Islami. Dar al Fikr Damsyiq.

Auda, J. 2008. Maqasid al-Syariah and Introductory Guide. Herndon: International Institute of Islamic Thought (IIIT)

Auda, J. 2008. Maqasid Al-Syariah as Philosophy of Islamic Law: A System Approach. Malaysia: The International Institute of Advanced Islamic Studies (IASC).

Department of Statistics Malaysia. 2016. Population distribution and basic demographic characteristics. Available at http://www.statistic.gov.my/poral/download_population/ fi;es/cencus2010/Taburan_penduduk_dan_ciri-ciri_asas_demographi.pdf.

Department of Statistics Malaysia. 2016. Report of household income and basic Amenities Survey 2016. Available at http://www.dosm.gov.my/v1/index.php?r=column/ctheme ByCat\&cat=120\&bul_id=RUZ5REwveU1ra1hGL21JWVIPRmU2Zz09\&menu_id=amV oWU54UT10a21NWmdhMjFMMWcyZz09.

Economic Planning Unit. 2009. The highest hardcore poor. Available at http://www.epu.gov.my.

Federal Consittution of Malaysia, Article 60.

Hamat, Z, 2012. Skim bantuan modal perniagaan di institusi zakat di Malaysia. Available at http://www.zahrihamat.com/2012/11skim-bantuan-modal-perniagaan.

Laporan Ekonomi - Negeri Kelantan Darul Naim 2010-2011. 2012. Unit Perancang Ekonomi Negeri Kelantan. Kelantan: Pejabat Setiausaha Kerajaan.

Mahyudin, A.B. \& Abdullah, A.G. 2011. Towards achieving the quality of life on the management of zakat distribution to the rightful recipients (the poor and needy). International Journal of Business and Social Sciences 2(4): 237 -245.

Rosbi, A.R., Sanep, A. \& Hailani, M.T. 2009. Keberkesanan agihan zakat mengikut perspektif Maqasid al-Syariah. Seminar Antara bangsa Muamalat Kewangan Ekonomi Islam, Universiti Kebangsaan Malaysia.

Rosbi, A.R. \& Sanep, A. 2011. Kesan kerohanian program bantuan modal asnaf oleh Lembaga Zakat Selangor (LZS). Proceedings The World Universities $1^{\text {st }}$ Conference, 22-24 November, Zakat Research Institute of Malaysia (IKaZ), UniversitiTeknologi MARA. 
Rosbi, A.R. \& Sanep, A. 2010. Keperluan asas berdasarkan Maqasid al-Syariah: Kearah pencapaian matlamat dan penilaian kemprehensif agihan zakat. Zakat Transformation: From Subsistence to Productive. Proceedings of the $4^{\text {th }}$ ISDEV International Islamic Development Management Conference (IDMAC 2010). $21^{\text {st }}-22^{\text {nd }}$ December 2010. Universiti Sains Malaysia.

Zakaria, M. 2014. The influence of human needs in the perspective of Maqasid al-Syariah on Zakat Distribution Effectiveness. Asian Social Science 10 (3), 165 - 173.

Zakaria, M. \& Ab Malek, N. 2014. Effects of human needs based on the integration of needs as stipulated in Maqasid Syariah and Maslow's hierarchy of needs on zakah distribution. JurnalPengurusan 40: 41 -52.

Zakariah, A.R., Amini A.A. \& Ahmad Fahme, M.A. 2010. Peranan agihan zakat dalam mengurangkan jurang kemiskinan: Satu kajian di Kelantan. Proceedings of the $4^{\text {th }}$ ISDEV International Islamic Development Management Conference (IDMAC 2010). $21^{\text {st }}-22^{\text {nd }}$ December 2010. Universiti Sains Malaysia.

Zakaria, M. \& Abd Malek, N.A. 2014. Effects of human needs based on the integration of needs as stipulated in Maqasid Syariah and Maslow's hierarchy of needs in zakah distribution efficiency of Asnaf Assistance Business Program. Jurnal Pengurusan 40: 41 -52 .

Maheran Zakaria (corresponding author)

Faculty of Accountancy

Universiti Teknologi MARA Kelantan

18500 Bukit Ilmu, Machang, Kelantan, MALAYSIA.

E-Mail: maher835@uitm.edu.my

Norhayati Samba Mohamad

Faculty of Accountancy

Universiti Teknologi MARA Kelantan

18500 Bukit Ilmu, Machang, Kelantan, MALAYSIA.

E-Mail: yatisamba@yahoo.com 